\section{A Tocquevillian Examination of Individualism in Early American Federalism}

Jean-Luc Plante

Royal Military College of Canada

"From the dawn of the colonial era, long before they even had a national identity, Americans have always felt they had a special role in the world..."(Rosenberg, 2011)

Many pundits commenting on early American affairs, such as Alexis de Tocqueville, believed that the United States of America benefitted from a unique societal and geographic context which would ultimately drive the narrative behind what is now being called American exceptionalism. This unique experience has permeated almost all facets of its state-centric federal system. The maximization of individual liberty was a driving factor in the American Revolution and it continued to drive a unique sense of nationalism which was later evoked on a continental basis. The American Revolution gave rise to a national emancipation movement driven by the revisionist values of liberty, egalitarianism, individualism and populism. The American Revolution held these values highly and attempted to redress longstanding grievances with an oppressive colonial master. Despite the appeal that liberty and egalitarianism had to the American individual, the United States had not completely broken away from European history, as it had retained class inequities, imperialism and war. The inescapable influences and pervasions of the old world would invariably conflict with the nationalistically driven ideals of emancipation, where the maximization of individual freedom, through the nation is seen as the true definition of freedom

In early post-revolutionary America, the United States was a loosely organized coalition of states which coordinated their actions through a centralized government, and where the individual states would reluctantly concede their powers to the central through a constitutional agreement. Evidently, the United States of America may have started out as a confederation which had shared powers and responsibilities between its constituents, however, the fact that the American state construct degenerated into a federation (where the powers of the state are highly concentrated in a central authority) speaks to Tocqueville's main point of criticism: that the inherent tyranny of the majority will eventually erode the democratic foundations of the American state concentrating true political power in the hands of few selected elites. In this case, the tyranny of the majority means that decisions are made by a majority inherently will cater to its interests so far above those of an individual or minority group as to constitute active oppression (Mill \& Currin 1996, 7)

In 1831, Alexis de Tocqueville went to America under the pretext of studying their prison system, but as a French aristocrat his implicit intent was to observe the inner workings of those equalitarian democratic doctrines that must ultimately become France's destiny as they were in America. He focused on how America's institutions, mores and society have been shaped and directed to mitigate the inherent tyranny of a majority, as it is often associated with democratically governed states. But how does this exactly relate to nationalism? Well, as a brief overview of how the logical argumentation in this paper is to develop, it begins with a Tocquevillian understanding of the tyranny of the majority; the majority in this case happens to be a nation in its own right, and the tyranny it imposes, by way of the government, ultimately delineates the role of the individual in society. This paper's analysis will take a rather holistic approach in examining each level of the American federal state apparatus, which invariably includes the American people and ultimately the singular individual, in order to demonstrate the following thesis: the role of an individual in a federal system, within the established framework of nationalism, is that of subordination. This thesis will be developed by first examining individualism within the American nationalist ideology. This concept of the individual will be compared to the American societal framework of democratic despotism, and finally the role of an individual will be explained in relation to the federal construct of democratic despotism.

\section{American Individualism in Nationalism}

Alexis de Tocqueville, being the first to critically examine the American state construct, believed that it was not only the emancipation from British rule that drove this nationalistic movement, but rather "a thousand special causes ... have singularly concurred to fix the mind of the American upon purely practical objects" (Rosenberg, 2011). In Tocqueville's examination of post-revolutionary America, he believed that an individual's loyalty was based on proximity, where an inherent hierarchy of loyalties developed from the citizen himself to his family, to his community, to his state, and finally to the whole of the union. This bottom up system of loyalty can, and did in the American Civil war, conflict with the top-down approach of subordination found in most federal arrangements. Although 
confederations may skew the conceptual framework of a federal system, this is only a slight deviance from the core argument that the individual is ultimately subjugated to the will of his nation. As Tocqueville has noted in his work Democracy in America, this sort of hierarchy of loyalties eventually culminates into the tyrannical rule of the majority, and given the top down structure of the American federal system, the individual's role is that of subordination to his family, to his community, to his state and finally to his nation.

Of course, one of the first problems we face in attempting to demonstrate the role of the individual within nationalism is that almost no one has explicitly written on this subject. However, those who had done so, would not expand upon the exiting ideological framework of nationalism far enough as to include a conceptual role of the individual. For example, Vincent has been reluctant to assign a role to the individual within nationalism due to its constantly changing and easily mutable nature instead opting for Ernst Renan's simplistic spiritual principle (Vincent 2009, 234). Despite this, he does reluctantly admit the possibility that the role of the individual can be understood through his community, and ultimately his nation (Vincent 2009, 240). However Vincent is not alone in adopting a rather holistic approach in order to understand the role of the individual within a nationalistic society. Both Johann Gottfried Herder and Johann Gottlieb Fichte had understood the role of the individual through a common humanity (Humanität) devoid of immediate local and intrusive ideological pervasions (Ball 2006, 172). That said, one must invariably examine the relationship of the individual to society, as opposed to the individual himself, if one wants to develop a legitimate conception of the individual within a nationalistic society. One of the problems with nationalism is that it is often understood in terms of localism and particularity of one nation (Vincent 2009, 228). More often than not, the role of the individual in these particular cases is often based on other ideological pervasions, which are not at all exclusive to the ideology of nationalism. Another fundamental assumption that must be made here is that nationalism can produce a standalone ideological framework upon which societies can be socially constructed. Unfortunately, if this paper seeks to establish a cross cutting concept of human nature, particularly the role of the individual in nationalism, it will have to examine aspects of nationalistic locality and particularity. In examining the American nation, the aspects of locality and particularity will draw upon the findings of Alexis de Tocqueville, as they were written in his exploratory work Democracy in America.

Vol. 13 Federalism-E

\section{Democratic Despotism}

The inherent tyranny of the majority was a fearful concept born out of Tocqueville's aristocratic analysis of the French revolution and its subsequent democratic principles. Democracy, as it is understood in the context of the American nation, was a deliberate attempt to reconcile liberty and equality. From the township, to the whole of the American nation, each different level of government was built upon the democratic foundations and practices of its smaller constituencies. Tocqueville warned that the democratic principles in place might eventually degenerate into despotism, which invariably would culminate into an illegitimate, absolute political leadership (Marchall \& Drescher 1968, 512-532). This particular type democratic despotism implies that the tyrannical rule of the majority is absolute at all levels of government, because the American people have the ability to democratically select their municipal, state, federal and the executive leadership. Once selected through popular consensus these individuals elect rule with the power of the people, which is itself the ultimate source of authority according to the American constitutional arrangement. The tyrannical rule of the majority is absolute at all levels of government, because it derives it power from an absolute source according to the American constitution, namely the American people.

Tocqueville believed that unless adequate safeguards were established against the inherent tyranny of the majority, degeneration into democratic despotism would be inevitable. Tocqueville found that America was far from a democracy, but rather it appeared to function as a republic with democratic elements. One of these democratic elements was the election of leaders at various levels of government through popular consensus; leaders who, once elected, would be free to determine policy without public consent, at least until the next election. The equalitarian values of the American Revolution were repetitively restrained and perpetuated by means of an electoral system, which in itself reinforced the logistical need for a despotic class of rulers to make policy decisions on an almost daily basis. The very fact that it is not people themselves who determine policy on a daily basis, but rather submit themselves to the will of a democratically elected system of despots is itself the epitome of democratic despotism. Government officials, who make the bulk of American policy decisions, are mostly democratically elected by the will of the American majority. In this case, the will of the American majority has been pervaded by the equalitarian values of religion as well as a sense of continental patriotism, which was then later strengthened through the American Revolution. It was through 
the American Revolution that the true characteristics of American Nationalism would be born out of, and ultimately helped define the American nation.

It is in his early observations that Tocqueville vaguely outlines what is the American nation, which of course completely excludes both the Native Americans and the African Americans. As to why the omission of these two groups (were somewhat excluded in) from his analysis of the American nation might simply be just a question of practicality; as no noble French man would have seen the use in conversing with such people, but at the same time, it allows for a more homogenous concept of the American nation-state: "The term nation usually denotes a group of people who have some common ancestry, history culture and language, which figure as a focus of symbolic loyalty and affection" (Vincent 2009, 227). How this applies to the American nation is quite evident, as America was founded by puritanical pilgrims who sought to create a society which truly represented their religious belief system. These very same pilgrims did not experience any significant hardship in their mother country, as they were usually well educated and wealthy. However, they came to America so that they might live their lives in a somewhat puritanical Christian fashion. In doing so, they came to America essentially under the same socio-economic conditions and given their common origin, this invariably enabled a sort of common ancestry, history, culture and language. From the arrival of the first pilgrims, to when Tocqueville actually set foot in America, there must have been some reasons as to why these national bonds remained unchanged throughout what was to become the common history of the American nation. The unclaimed vastness of the American landscape provided opportunities that were uncommon everywhere else around the globe, and in this case appeared to be virtually endless. Whereas most of the European nations at the time had already expanded to the inherent limits of their territory, the Americans were continually expanding and continued to do so at an alarming rate (Tocqueville 1957, 142). In turn, this continual expansion allowed the American Nation to expand its language, culture, religion and other such national characteristics largely because they were left unhindered by the pervasive influences of other nations as it was the case in Europe.

Territorial considerations alone would not be sufficient in maintaining this American national homogeneity, as culture would have an even greater impact on not just the nation, but the individuals within a nation. In America, individuals who differed slightly from the majority in any fashion would invariably be conditioned by American laws to adopt a similar lifestyle, and thus began the "forceful" creation of a largely homogenous Anglo American society, or better yet, a true nation-state.
Since its inception, the America Nation has raised formidable barriers around the liberty of opinion, where one is generally shunned for adopting ideas, or a lifestyle, that differs from that of the majority. In fact, Tocqueville believes that it is not a freedom of speech that is absent in America, but rather a freedom of opinion. (Tocqueville 1957, 114) This coercive aspect of American society served to encourage an equally insidious form of tyranny which made governmental participation unnecessary (Horrowitz 1996, 297). In the American context, the majority not only regulated the actions of men by virtue of a numerical superiority, but it also manipulated their political will as to suit the interests of the majority (Horrowitz 1996, 301). Any amendment to the American constitutional arrangement, which ultimately defines the American nation as well as its federal structure, requires the support of two thirds of the state legislatures. The majority alone has the power to modify this constitutional arrangement, which serves to regulate the actions of men and ultimately to define the American nation. The link between the American nation and the majority is apparent in light of the requirements for constitutional amendments. Tocqueville appears to be absolutely correct in his belief that despotism had arrived at a new stage of perfection, since those who were oppressed glorified their oppression and honoured their oppressor (Horrowitz 1966, 303). Although, one must understand that such vindication, took place under the veil of patriotism and nationalism.

\section{Federal Construct of Democratic Despotism}

Now why would individuals willingly support strong nationalist movements which would ultimately seek to subordinate these very same individuals by means of a democratic despotism? From the individual's standpoint, it seems almost counter intuitive to willingly give up your own freedoms in a nationalistic fervour, yet this is exactly what happened to the puritanical pilgrims who founded the American nation. The majority of the actions undertaken by the American state were accomplished by society for society, as every individual had both a share and a vested interest in the powers of statecraft. "The nation participates in the making of its laws by the choice of its legislature and in the execution of them by the choice of the agents of the executive government; it may almost govern itself executors, so feeble and so restricted is the share left to the administration, so little do the authorities forget their popular origin and the power from which they emanate" (Tocqueville 1957, 56-57). As legislation in America was usually voted in by popular consensus, this empowered the individual with enormous political clout. However, the political power of popular consensus would be heavily restrained in its application, as no 
individual would dare use it against his national community. In terms of the formulation of legislation, it appears that America is has no real way to escape the tyrannical rule imposed upon it by way of democratic despotism. Despite this, the individual still believes that nationalism simply provides a strong vehicle, through which his or her interest may be pursued. Personal interests will rarely triumph in issues considered to be of national interest, as the nation invariably has more power than the individual just on the fact that majority, which is embodied by the nation, is far stronger than its constituents. Given the popularized forms of patriotism, nationalism in itself is often seen as a form of emancipation, but in reality it continues to subordinate the individual to the federal state.

The American federal state is crafted in such a fashion, as to perpetuate the democratic despotism that Tocqueville was so fearful of into every facet of the American government. The consensual democratically inclined decision making model implemented at each level of government reinforces the tyranny of the majority. Each level of government is a majority in its own right; however its interaction with other "majority" governments makes it a minority in its own right. Quite simply for an individual to be elected in the American system one must win the majority of votes, then policy decisions at the state and federal levels are determined by the majority of these elected officials. The compounded effect of succeeding levels of tyrannical majorities eventually leads to the creation of democratically despotic federal state. The individual freedoms enjoyed by the average American citizen where no different in pre-revolutionary America because back then "colonists were [also] subject to multiple ascending layers of political authority (i.e., colonial legislature, royal governor, Parliament, Privy Council), [and] only a minor conceptual adjustment was needed following independence to establish the Constitution's two-level federal structure of state and national authority" (Lacroix 2010, 453).

Given that America had been founded by thirteen separate colonies that were once united against a common enemy, it should be of no surprise that certain vestiges of these colonies remain within the current constitutional arrangement. This is in part reflected in the sovereignty that is allocated to each of these different states within the union. However, it was foreseen that eventually questions of authority would arise to which no ordinary court would be fit to arbitrate such matters. "Thus, a high federal Court was created; one of whose duties was to maintain the balance of power between the two rival governments, as it had been established by the constitution." (Tocqueville 1957, 79) This constitutional court appeared in a sense to provide a genuine safeguard against the supposed tyranny of the majority, and its adjudication would greatly expand the powers and responsibilities of the federal government. In fact, "the national authority is more centralized there than it was in most of the absolute monarchies of Europe..." (Tocqueville 1957, 80). The independence of a strong judiciary could essentially disintegrate the very core of the democratically despotic federal system, which was dependent on imposing the will of a majority upon minorities at various levels of government. By creating this powerful and independent institution, which would be able to mediate between state and general governments, "they gave their institutional choice of a judicial approach a normative edge. The Revolutionary belief in multiplicity thus melded with a new structural commitment to a judicial solution. The result was both ideology and institution, and it was called federalism" (Lacroix 2010, 458). Although federalism itself was an ingenious construct, it still had to contend with mores and beliefs of local institutions which strengthened the resolve of each township which still carried on the values of independence from the revolutionary war.

The laws that governed these societies, or townships as this was the exact entity that Tocqueville referred to, were almost always implemented by popular consensus. It would be through the voice of the majority that the particular moral codes which governed these townships would be forged. For example, "they continually exercised the rights of sovereignty; they named their magistrates, concluded peace or declared war, made police regulations and enacted laws, as if their allegiance was only due to God" (Tocqueville 1957, 44). In these American townships, it would seem that both democracy and religion had been mutually supportive elements, which acted as the very foundations of American nation. The pressure to conform into a homogenous nation is incredibly strong in America, as well there appears to be very few limitations on how society may exert these conforming pressures where even the constitution, the laws, and the government at all levels are bound to obey the will of the majority. The American nation, in both its culture and its institutions of government, subordinates the individual to the nation as a whole...Tocqueville seems to indicate just that, in reference to democracy; "I have already observed that the advantage of democracy is not, as has been sometimes asserted, that it protects the interests of all, but simply that it protects those of the majority. In the United States, where the poor rule, the rich have always something to fear from the abuse of their power." (Tocqueville 1957, 108)

The judicial system in America was indeed quite unique, but at the same time it functioned much like its European counterparts. For example, much like the 
French judiciary, an "American judge can only pronounce a decision when litigation has arisen, he is conversant only with special cases, and he cannot act until the cause has been duly brought before the court" (Tocqueville 1957, 75). Given that this is very much the same function that any European magistrate would fulfill, how is it that the American is so different that Tocqueville finds it absolutely necessary to devote a significant portion of his first book on this very issue? "[Tocqueville] did not concern himself with the efficacy of the jury system in administering justice. Rather, he applauded the opportunity that the jury trial gave to judges and lawyers, men of learning and respectable position in society, to instruct the populace at large about the virtues of order, precedent, and tradition" (Marchall and Drescher 1968, 528). One of the, if not the most important, difference between the American and the European judiciary is that "the Americans have acknowledge the right of judges to found their decisions on the constitution rather than on the laws" (Tocqueville 1957, 74). This in turn enables judges routinely, if they so please it, to nullify certain laws that originated from the respective legislative bodies of the state. This could lead to legislative bodies being easily dismissed by the whims of judges. In turn, this greatly increases the political power of said judges. In France judges are obliged to render verdict upon established laws, but in America judges are free to speculate on the constitutional validity of these laws and as such they may be omitted from judicial proceeding altogether. As to why the American have entrusted their judges with such powers is something that baffles Tocqueville, yet he does acknowledge that this is a good thing for America, assuming of course that judges are chosen based on their professional capabilities as opposed to simple popularity. Tocqueville believes that "the power vested in the American courts of justice, of pronouncing a statute to be unconstitutional, forms one of the most powerful barriers which has ever been devised against the tyranny of political assemblies." (Tocqueville 1957, 79) However, this does not imply that judges may be able to overturn the will of the majority, as the very constitution that judge can use to nullify certain state-based laws is in itself an embodiment of America's democratic despotism.

The constitution is the origin of all authority and the sole vehicle of predominant force, and in America it is essentially the law of laws. The constitution in America is unique, in so far as it is bound to the will of the people, where amending it requires referendums based on a popular consensus; "...the constitutional mechanisms created by the U.S. framers -the whole "Madisonian" system of checks and balances - are insufficient to stop, and may even encourage the pressures of democratic sovereignty and majority tyranny" (Kraynak 1987, 1187). It would seem that the constitution in itself is an embodiment of the supposed tyranny of the majority, and encourages the creation of a democratically despotic regime within a federal framework. Despite being considered the "supreme" law of the United States of America, the constitution itself can easily be amended at the whim of the current tyrannical majority. Amendments to the constitution, require a national super majority of $67 \%$ in Congress, both House (people) and Senate (states) and then a super-super $75 \%$ majority of the states ratifying, which represents a majority of the people in the states ratifying (Lutz 1994). These "majority-rule" safeguards to the constitutional order were introduced into the constitutional arrangement at the expense of the individual who must submit himself to compounded levels of despotic majorities, who themselves are unable to encroach upon other legislative bodies, but may freely subjugated minorities in their respective constituents. The inclusion of an American Bill of Rights may have seems to be a safeguard against the tyrannical rule of the majority, as it required jury trials and a fundamental right to bear arms. However, one must understand that in jury trials, the American individual is still tried by a "tyrannical majority," because the jury itself offers a final verdict of guilt or innocence based on the consensus of its members. Furthermore, members of a jury itself are legally bound to render judgement on the actions of the individual against the backdrop of laws that were themselves product of a tyrannical majority. Understandably, Tocqueville makes an important distinction between both the social mores of the American people and their legal system; in so far that he isolates the constitutional system from whole social order. The use of juries in the American context reinforces Tocqueville's point that it is not the freedom of speech that is absent in America, but rather the freedom of opinion and this argument extends to the creation of legislation and ultimately the constitutional arrangement itself.

Given that the Americans have founded a democratic republic, there is no real mechanism in place to stop the supposed tyranny of the majority, which would then be free to change the constitution if it does not in fact reflect the will of the democratically governed despotic order. According to Toqueville's observations, the democratic despotic order in the United States had not yet been carried to dangerous excesses, but it would inevitably do so according to President Madison. That being said, the central government believed it necessary to limit these tyrannical statebased majorities by the imposition of a veto power in the federal government (Lacroix 2011, 42-45). This re-asserts this paper's belief that the American federal system is a series of despotic majorities compounded upon each other in a series of ascending layers of government to which the individual is ultimately subordinated to the tyranny of such a "majority"; "The effect of incorporating the federal negative into the amended charter, [Madison] wrote, would be "not only to guard the 
national rights and interests against invasion, but also to restrain the States from thwarting and molesting each other, and even from oppressing the minority within themselves by paper money and other unrighteous measures which favour the interest of the majority." (Lacroix 2010, 463) Unfortunately, Madison did not win this debate and the so called "federal negative" was shelved, perhaps due to the remorseful feelings of a previous imperial government. That being said, the tyranny of the majority was free to exert its perverted influences on the American judicial system and further enshrined the system of democratic despotism through the existing constitutional arrangement.

\section{Conclusion}

In conclusion, there is in fact a nationalist conception for the individual within federalism; the role of the individual will always be one of subordination to the national interest of his or her respective nation. As Tocqueville understood it, the American nation exerted considerable controls over the individuals in its society. Despite possible feelings of emancipation and empowerment in the American political system, individuals are unable to really do anything if it is deemed to be against the interests of their nation. The internal pressures of the American community have eroded the real political powers of the individual in favour of a more homogenous society, which furthers its interest by pressuring individuals into a collective mindset. Given the Tocquevillian understanding of the tyranny of the majority (the majority in this case happened to be a nation in its own right and the tyranny it imposed, by way of the federal government, delineated the subordinate role of the individual in society). Within the American federal system, nationalism has not entirely emancipated the individual, but rather has subjugated him to the will of the nation, or the federation. The real test for this particular conception of the individual in federalism would rest in its applicability to what history has labelled "federalist states". If this can be done legitimately, then there is no doubt that this particular nationalistic conception of the individual in a federal system holds true and as such it will most likely further knowledge in this field. What this paper has done is lay the down framework for such a conception; however it does not prove very much on its own... unless the breath of cases is expanded and the inherent anachronistic arguments presented by Tocqueville are substantiated by modern sources. 


\section{Bibliography}

Ball, Terence. "Nationalism." Political Ideologies and the Democratic Ideal.Toronto: Pearson Longman, 2006. 172.

Hancock, Ralph C. "Tocqueville on the Good of American Federalism." Publius (Oxford Univeristy Press) 20, no. 2 (1990): 89-108.

Horrowitz, Morton J., Tocqueville and the Tyranny of the Majority, Review of Politics, 28:3( 1996:July). 293-307.

Kraynak, Robert P. "Tocqueville's Constitutionalism." The American Political Science Review 81, no. 4 (December 1987): 1175-1195.

Marchall, Lynn L, and Seymour Drescher. "Historians and Tocqueville's Democracy." The Journal of American History, 1968: 512-532.

LaCroix, Alison L. The Ideological Origins of American Federalism. Cambridge, MA: Harvard UP, 2010

LaCroix, Alison L. What if Madison had won? Imagining a constitutional world of legislative supremacy. Indiana Law Review. Vol. 45:4. (2011): 41-59.

Lutz, Donald S. Toward a Theory of Constitutional Amendment. The American Political Science Review Vol. 88, No. 2 (Jun., 1994), 355-370.

Mill, John Stuart, and Currin V. Shields. On Liberty. Upper Saddle River, NJ: Prentice Hall, 1996.

Rosenberg, Paul. American deceptionalism. Al Jazeera. Last modified March 26, 2012. http://www.aljazeera.com/indepth/opinion/2011/11/20.html

Tocqueville, Alexis de. Democracy in America. Translated by Richard D. Heffner. New York, New York: Mentor books, 1957.

Vincent, Andrew. "Nationalism." Modern Political Ideologies. Chichester, U.K.: Wiley-Blackwell, 2009. 